Tolmie, DF

Universiteit van die Vrystaat

\title{
Die narratologiese analise van randfigure: Die siekes as groepskarakter in die Johannes-evangelie
}

\author{
ABSTRACT
}

The narratological analysis of background characters: The ill as group character in the Gospel according to John

Since the first narratological/narrative critical studies of the Gospel of John were published several decades ago, much effort has been put into the analysis of characterization in this Gospel, and the value of such approaches has been proved. A survey of such studies indicates that scholars usually focus their narratological analyses on the main and minor characters in the Gospel. Thus far background characters have not been considered from such a perspective. In this article this issue is addressed and an example of a narratological analysis of such a group of characters, namely the ill (John 5:2-3 and 6:2), is offered. Aspects that are considered include the classification of this group character, the settings within which it appears, and the role of the reader in its construction.

\section{INLEIDING}

Een van die vrugbaarste ontwikkelings in die uitleg van Bybeltekste die afgelope paar dekades was die belangstelling in die narratologiese/narratief-kritiese lees van tekste, waarvan een van die fasette die ondersoek van die manier is waarop karakters in Bybeltekste uitgebeeld word. In die geval van die Johannes-evangelie was dit Alan Culpepper (1983) wat die eerste volledige narratologiese ondersoek van die Johannes-evangelie gepubliseer het. In die gedeelte waarin hy die karakterisering in die Johannes-evangelie behandel, bespreek hy al die belangrike karakters in dié Evangelie - in totaal nie minder nie as 24 karakters!

Sedertdien het daar talle studies oor Johannese karakters verskyn en is die nut van sulke benaderings al male sonder tal aangetoon. Wanneer karakterisering in die Johannes-evangelie ondersoek word, fokus navorsers gewoonlik óf op'n groep karakters óf op een of twee van die hoofkarakters in die Evangelie.

Om enkele voorbeelde te noem:'n Groep karakters: Margaret Davies (1992:316-349) bespreek 20 karakters, Peter Dschulnigg (2002) 21 karakters, Craig Koester (Koester 1995:33-77) 14 karakters en Cornelis Bennema (2009) 23 karakters; Sandra Schneiders (1993) en Adeline Fehribach (1998) fokus slegs op die vroulike karakters in die Johannes-evangelie terwyl Colleen Conway (1999) die karakterisering van vyf manlike en vyf vroulike karakters bespreek. Individuele karakters waarvan die karakterisering gereeld aandag in die navorsing kry, is die Moeder van Jesus, byvoorbeeld David Beck (1993:143-158) en Judith Hartenstein (2007:269294); Petrus, byvoorbeeld Helen Bond (1998:174-193) en Timothy Wiarda (2000); Pilatus, byvoorbeeld Martin de Boer (2000:141-158) en Christopher Tuckett (2000:131-140); "die Jode", byvoorbeeld Gérald Caron (1997) en Tobias Nicklas (2001); en Maria Magdalena, byvoorbeeld Susanne Ruschmann (2002), Reimund Bieringer (2005:34-41) en Andrea Taschl-Erber (2007). 
NGTT: Oopbron - http://ngtt.journals.ac.za

Soos uit hierdie lys voorbeelde blyk, is dit gewoonlik hoofkarakters en/of kleiner karakters (die sogenaamde "minor characters") wat aandag kry wanneer karakterisering in die Johannesevangelie aan die bod kom. Daar is egter een groep karakters wat sover ek kon vasstel, nog nooit aandag in sulke studies gekry het nie. Dit is die groep karakters wat ek "randfigure" noem. (Later meer oor die benaming "randfigure.") Daarmee verwys ek na karakters wat as't ware net vir'n vlietende oomblik in die narratiewe wêreld van die Johannes-evangelie verskyn - karakters op wie die kollig nie langer as 'n enkele moment val voordat die verhaal voortsnel na die finale ontknoping nie.

Die feit dat sulke randfigure gewoonlik nie baie aandag in narratologiese studies kry nie (gewoonlik ook nie in kommentare nie!) het waarskynlik primêr daarmee te doen dat navorsers van mening is dat daar nie veel vanuit narratologiese perspektief oor sulke karakters gesê kan word nie, en dat dit dus nie die moeite werd is om die narratologiese rol wat hulle vervul, verder te verken nie. Die bedoeling van hierdie artikel is om hierdie aanname krities te ondersoek en verkeerd te bewys, deur die kollig op een so 'n groep randfigure te laat val, naamlik die siekes in die Johannes-evangelie. In narratologiese terme kan van hierdie groep as 'n groepskarakter gepraat word. ${ }^{1}$

Hierdie studie probeer 'n leemte in die Johannese narratologiese navorsing te vul en die bruikbaarheid van narratologiese benaderings te demonstreer in gevalle waar dit moontlik met die eerste oogopslag minder belowend lyk. Die vraag wat dus gestel word, is hoe ' $n$ groep randfigure soos die siekes in die Johannes-evangelie vrugbaar vanuit narratologiese perspektief ondersoek kan word. Een verdere belangrike opmerking moet hier aan die begin van die studie gemaak word. Die fokus in hierdie studie val spesifiek op 'n groepskarakter, naamlik die siekes wat as randfigure in die Johannes-evangelie verskyn en nie op die individuele siekes wat as kleiner figure ("minor characters") in dié Evangelie optree nie, byvoorbeeld die blindgeborene, die verlamde man en die blindgeborene nie.

\section{Die Siekes in die Johannes-EVANGelie}

Eksegete wys dikwels daarop dat daar ' $n$ verskil is tussen die manier waarop genesing in die Johannes-evangelie uitgebeeld word en die manier waarop dit in die Sinoptici uitgebeeld word. ${ }^{2}$ Uitgedruk in narratologiese terme: In die verhaalwêreld van die Johannes-evangelie vind die leser geen duiwel-uitdrywings, genesing deur handoplegging of die genesing van melaatses nie (Hogan 1992:277). John Pilch (2000:119) stel dit treffend:

Terms for healing appear twenty-five times in Luke, seventeen times in Matthew, and eight times in Mark. By contrast, there are only three healing stories in the entire Gospel of John (4:46-54; 5:1-20; 9:1-41). Moreover, none of these healing stories actually underscores Jesus' reputation. Rather, healing in John reveals Jesus' true identity, and the focus of the interaction surrounding the healing report rests on controversy with opponents. This controversy is always revealing since it makes even clearer who Jesus really is. The healing event itself fades into the background. ${ }^{3}$

1. Voorbeelde van ander groepskarakters in die Johannes-evangelie is die dissipels, die "Jode", die Samaritane, die Grieke en die groep vrouens by die kruis van Jesus.

2. Kyk byvoorbeeld Howard (2001:171).

3. Let daarop dat 'n mens die Lasarusverhaal ook as 'n genesing sou kon klassifiseer, wat beteken dat daar dan vier genesingsverhale in die Evangelie is. Pilch (2000:138) verwys ook self na hierdie moontlikheid. 
Daar word twee keer in die Johannes-evangelie na die siekes as 'n groepskarakter verwys, naamlik in Johannes 5:2-3 en in 6:2:

Die eerste voorkoms is in die verhaal oor die genesing by die Bad van Betsata ${ }^{4}$ (Johannes 5:147). Dié verhaal begin met 'n situering (5:1-5), gevolg deur die genesing (5:6-9), 'n gesprek tussen die "Jode" en die man (5:10-13), 'n kort gesprek tussen Jesus en die man (5:14), die man se terugvoer aan die "Jode" (5:15), en word afgesluit met 'n lang gedeelte waarin vertel word hoe die "Jode" teen Jesus te velde trek oor die feit dat die genesing op die Sabbat plaasgevind het, en hoe Jesus Homself teen hulle verweer (5:16-47). Die verwysing na die siekes as groepskarakter kom dus voor heel aan die begin van die verhaal (in die situering in 5:1-5) en

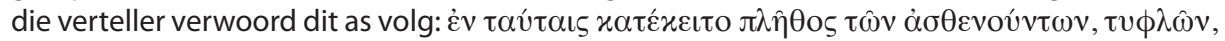
$\chi \omega \lambda \hat{\omega} v, \xi \eta \varrho \hat{v} v$. Hierna verskuif die fokus na 'n spesifieke individu in die groep, naamlik die man wat vir 38 jaar lank siek was, en die groep siekes verdwyn van die toneel.

Die tweede verwysing na siekes as'n groep kom in Johannes 6:2 voor, en wel in die inleidende gedeelte van die verhaal oor die vermeerdering van die brood. In 6:1 word vertel dat Jesus na die oorkant van die See van Galilea gegaan het. In die volgende vers word gesê dat 'n groot klomp mense Hom gevolg het, en die rede wat daarvoor aangegee word, is dat hulle

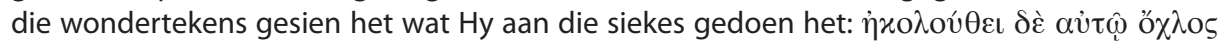

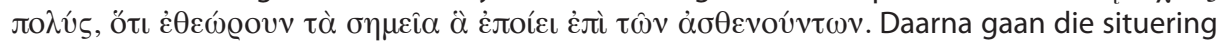
voort en word vertel dat Jesus die berg opgegaan het en met sy dissipels daar gaan sit het. In die geval van Johannes 6:2 verskyn die siekes dus nie self in die narratiewe wêreld nie, en word daar net op 'n indirekte manier na hulle verwys.

Allereers word gefokus op die terminologie wat gebruik word om hierdie groepskarakter te

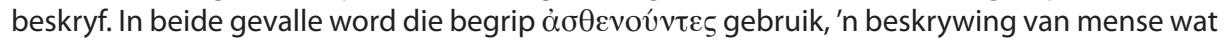
siek is. Louw en Nida (1988:23.144) plaas die woord in Semantiese Domein 23 ("Physiological processes and states") en vertaal dit as "ill", en in BDAG ( $\dot{\alpha} \sigma \theta \varepsilon v \varepsilon \omega)$ word dit verduidelik as "to suffer a debilitating illness, be sick." In Afrikaans kan die begrip dus as "siekes" vertaal word. ${ }^{5}$

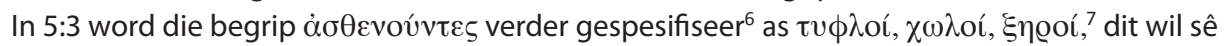
blindes, kreupeles en lammes.

Hoe word die verwysing na die siekes gewoonlik deur Johannese eksegete hanteer? In die geval van 5:3 is daar feitlik geen belangstelling in die groep as sodanig nie. Die enigste

4. Wat die naam van die bad betref, volg ek die lesing in Nestle-Aland ${ }^{28}: \mathrm{B} \eta \theta \zeta \alpha \theta \dot{\alpha}$. Ander opsies is

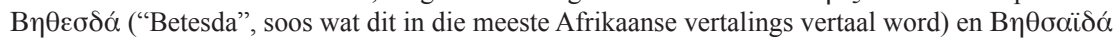
("Betsaïda"). Kyk die volgende vir goeie besprekings van hierdie komplekse teks-kritiese aangeleentheid, en ook vir die manier waarop die res van Johannes 5:2 geïnterpreteer kan word: Barrett (1978:251-253), Brown (1984:207-208) en Thyen (2005:297-298).

5. In Nuwe-Testamentiese navorsing word daar dikwels 'n onderskeid getref tussen "illness" en "disease", en daarmee saam tussen "healing" en "treatment", byvoorbeeld soos wat John Pilch (2000:24-25) doen. In hierdie artikel gebruik ek die Afrikaanse begrip "siekes" as 'n sambreelterm vir alle menslike ervaring van siekte (beide "illness" en "disease"). Die begrip "genesing” word eweneens in hierdie breër sin gebruik soos wat dit deur Pilch (2000:25) verduidelik word:

Healing is directed towards illness, that is, the attempt to provide personal and social meaning for the life problems created by sickness. Treatment, of course, can be concerned with one of the other aspect of a human problem (disease or illness), and either or both can be successfully treated.

6. So tereg Newman en Nida (1980:145).

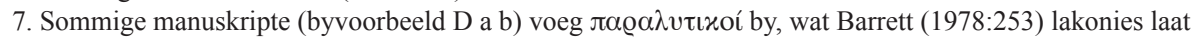
opmerk: “... a good example of the Western text's inability to know when to stop." 
NGTT: Oopbron - http://ngtt.journals.ac.za

aspek wat gewoonlik ter sprake kom, is die desperate situasie waarin sulke mense hulle in die antieke tyd bevind het. Enkele voorbeelde: Thomas Brodie (1993:235) beskryf die toneel as 'n situasie van "swarming suffering", John Chistopher Thomas (1995:6) verwys na hulle as "society's abandoned", en John Pilch (2000:128) as "the socially expendable, the unclean 'throw-away' peoples that could be found in every pre-industrial city". In die geval van 6:2 is daar gewoonlik net een aspek wat die aandag van eksegete trek, naamlik verbasing oor die feit dat daar skielik so 'n groot skare in die verhaal verskyn. So argumenteer Ernst Haenchen (1980:300) byvoorbeeld dat hierdie aspek nie logies voortvloei uit die verhaal soos wat dit tot op hierdie punt in die Johannes-evangelie vertel is nie, en stel dan voor dat dit eintlik 'n aspek is wat uit die Sinoptiese tradisie kom waarvolgens ' $n$ wye genesingsbediening deur Jesus in Galilea gereflekteer word - iets wat nie in die Johannes-evangelie uitgebeeld word nie. Hierdie aspek kan ook in narratologiese terme verwoord word, soos wat Steven Hunt (2011:241) doen: "John's narrative forces the reader to assume that Jesus has healed many others in addition to those mentioned in chapter 4 and $5^{\prime \prime}$.

Is daar enigiets meer wat vanuit 'n narratologiese raamwerk gesê kan word? Ek dink dat daar drie addisionele sake is wat aandag verg:

Eerstens, as groepskarakter is die siekes in die Johannes-evangelie 'n voorbeeld van ' $n$ tipe karakter wat "net-net" in die narratiewe wêreld bestaan. Vanuit teoretiese oogpunt kan 'n mens hierdie aspek die beste verduidelik deur gebruik te maak van die werk van die bekende narratoloog, Uri Margolin. In een van sy bydraes oor karakterisering (Margolin 1987:107-124), het hy die aandag gevestig op die minimum voorwaardes waaraan 'n karakter moet voldoen om in die narratiewe wêreld te "bestaan". Hy het vyf sulke voorwaardes geïdentifiseer, naamlik die eksistensiële dimensie (Kan 'n mens die karakter sonder twyfel as'n individu of as'n groep in die narratiewe wêreld identifiseer?); intensionele dimensie (Besit die bepaalde karakter 'n karaktereienskap, of, in Engels, "a trait"? ${ }^{8}$ ); uniekheid (Kan 'n mens die karakter duidelik onderskei van ander karakters in die verhaal?); paradigmatiese eenheid in beskrywing (Kan 'n mens die soort karakter wat ter sprake is, identifiseer?) en sintagmatiese kontinuïteit (Tot watter mate is daar sprake van verandering of ontwikkeling in die karakter?). Die siekes voldoen netnet aan hierdie minimum voorwaardes: Wat die eksistensiële dimensie betref: hulle word in

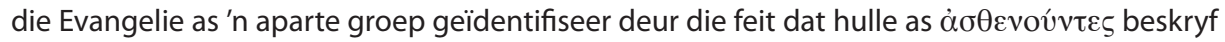
word; wat uniekheid betref: hulle word in die verhaal as ' $n$ aparte groep karakters uitgebeeld en daar bestaan nie'n moontlikheid dat die leser hulle met ander karakters sal verwar nie; wat die intensionele dimensie betref: hulle beskik oor slegs een karaktereienskap, naamlik die feit dat hulle siek is; wat paradigmatiese eenheid in beskrywing betref: hulle is deurgaans karakters wat hulp nodig het en op soek is na genesing; en wat sintagmatiese kontinuïteit betref: hulle behoort tot die groep karakters wat Margolin tipeer as karakters wat geen verandering (zero change) in die verhaal ondergaan nie. Die feit dat hierdie groep karakters net-net in die narratiewe wêreld bestaan, blyk uit die minimale wyse waarop hulle aan al vyf die genoemde voorwaardes voldoen, maar veral uit die feit dat hulle oor slegs een karaktereienskap beskik.

Dat hierdie groepskarakter net-net in die narratiewe wêreld bestaan, kan ook op 'n ander manier in terme van narratologiese raamwerke aangetoon word. Een van die belangrike aspekte wanneer karakterisering in verhalende tekste ondersoek word, is die klassifikasie van

8. Een van die maniere waarop karakterisering in verhalende tekste ondersoek word, is deur karakterisering te verstaan as die stelselmatige opbou van 'n versameling karaktereienskappe ('n sogenaamde "paradigm of traits"): Tydens die leesproses stel die leser vir elke karakter 'n lys van karaktereienskappe saam wat tydens die leesproses aangevul of verander word. Kyk byvoorbeeld Chatman (1978:119-133). 
karakters in terme van die verskillende kategorieë van karakters wat 'n mens in sulke tekste kan verwag. Die bekendste hiervan is die tweedeling wat wyd gebruik word, naamlik die onderskeid tussen hoofkarakters en kleiner karakters (die sogenaamde "minor characters"). In terme van hierdie onderskeid kan 'n mens die siekes in die Johannes-evangelie as kleiner karakters klassifiseer. 'n Mens voel egter dadelik aan dat so 'n onderskeid nie werklik sinvol is nie, want dit sou beteken dat hulle in dieselfde kategorie as karakters soos Andreas, Filippus, die Samaritaanse vrou, Lasarus, en so meer, geplaas word - almal karakters wat nie as hoofkarakters geklassifiseer sou kon word nie omdat hulle slegs enkele kere in die narratiewe wêreld hulle verskyning maak, maar wat tog'n heelwat belangriker rol in die verhaal speel as wat waar is van die siekes. Dit lyk dus beter om van ander klassifikasiesisteme gebruik te maak wat met meer as bloot twee klasse karakters werk. Ek kies drie sulke sisteme en toon telkens aan hoe die siekes in terme van die bepaalde sisteem geklassifiseer sou kon word:

W.J. Harvey (1965:52-57) onderskei tussen verskillende tipe karakters in verhalende tekste deur van 'n kontinuum gebruik te maak. Aan die een kant van die kontinuum plaas hy die protagoniste (die belangrike karakters in die verhaal) en aan die ander kant agtergrondkarakters (wie se enigste rol in die verhaal is om 'n klein rol in die "plot"van die verhaal te vervul). Tussen hierdie twee uiterstes onderskei hy nog twee tipe karakters, naamlik "cards" (karakters wat nie werklik protagoniste in die verhaal is nie, maar wel 'n belangrike rol speel) en "ficelles" (karakters wat meer volledig as die agtergrondkarakters uitgebeeld word, maar nogtans net bestaan om sekere funksies in die verhaal te vervul). In terme van hierdie klassifikasie is dit duidelik dat die siekes in die Johannes-evangelie as agtergrondkarakters geklassifiseer moet word, want hulle word baie skraps gekarakteriseer, en bestaan slegs om 'n agtergrondrol in die verhaal te speel.

Adele Berlin (1983:23-42) gebruik 'n drievoudige sisteem. Sy onderskei tussen karakters wat volledig ontwikkel word (sy noem hulle "full-fledged characters" of dan ook "ronde karakters"), tipes (karakters met enkele karaktereienskappe, gewoonlik beskryf as "plat karakters"), en "functionaries" (karakters wat glad nie gekarakteriseer word nie, maar net bestaan om 'n bepaalde rol of funksie in die verhaal te vervul). In terme van hierdie klassifikasie sal die siekes in die Johannes-evangelie as "functionaries" geklassifiseer moet word.

James Resseguie (2005:122-125) onderskei tussen vyf tipe karakters in verhalende tekste. Hy gebruik die bekende onderskeiding tussen "ronde" en "plat" karakters,9 maar voeg nog drie kategorieë by: "stocks", "foils" en "walk-ons". Vir die definisie van "walk-ons" maak hy gebruik van Chatman (1978:141) se definisie waarvolgens sulke karakters nie volledig gekarakteriseer word nie, maar in der waarheid deel uitmaak van die agtergrond en situering van die verhaal is. In terme van die kategorieë wat Resseguie onderskei, sal die siekes in die Johannes-evangelie dus gekategoriseer word as "walk-ons".

Om saam te vat, uit bogenoemde bespreking is dit duidelik dat die siekes in die Johannesevangelie wel op tegniese vlak as karakters in die verhaal geklassifiseer kan word, maar hulle bestaan net-net binne die verhaalwêreld. Afhangende van die klassifikasiesisteem wat' $n$ mens gebruik, is hulle "agtergrondfigure", "functionaries" of "walk-ons". Dalk is die beste beskrywing om hierdie minimalistiese rol binne die narratiewe wêreld in Afrikaans te beskryf die begrip "randfigure" - die begrip wat ook vir die titel van hierdie artikel gekies is.

9. Die bekende onderskeid tussen "ronde" en "plat" karakters is reeds dekades gelede deur E.M. Forster (1927:67-78) getref, maar word nog steeds wyd gebruik. Vir kritiek op hierdie onderskeiding, kyk Beekman en Fontijn (1971:406-413). 
NGTT: Oopbron - http://ngtt.journals.ac.za

'n Tweede belangrike faset wat verdere ondersoek verg, is die situering ("setting") waarbinne die siekes in die Johannes-evangelie geplaas word, want soos Shlomith Rimmon-Kenan (1983:6667) tereg in haar teoretiese raamwerk vir narratologiese analise aandui, speel situering dikwels 'n belangrike rol in die uitbeelding van karakters.

In die geval van Johannes 5:2-3 word die siekes langs die Bad van Betsata geplaas, dus langs ' $n$ groot bad met water. Soos wat John Christopher Thomas (1995:6-7) reeds tereg uitgewys het, is hierdie situering van die siekes langs water baie belangrik, aangesien water tot op hierdie stadium ' $n$ besondere rol in die Johannes-evangelie gespeel het: die doop van Johannes (Johannes 1:25-28, 33; 3:23), die wynwonder waar water in wyn verander word (Johannes 2:111), die klem op die noodsaaklikheid van geboorte uit water en Gees (Johannes 3:5), die feit dat Jesus se dissipels mense gedoop het (Johannes 4:2) en die gesprek oor die lewende water tussen Jesus en die Samaritaanse vrou (Johannes 4:19-25). Thomas (1995:6) merk tereg op dat die situering van die siekes langs water daartoe sal lei dat sekere verwagtinge by die leser by voorbaat geprikkel sal word. Myns insiens is daar ' $n$ verdere moment in hierdie situering wat belangrik is, naamlik dat daar moontlik ook 'n moment van ironie in die situering kan wees. As 'n mens in gedagte hou dat water dikwels op simboliese manier in die Johannes-evangelie gebruik word om die oorvloed van die lewe wat deur die Seun van God gebring word, aan te dui, is die skerp kontras tussen die situering langs water en die hooplose toestand waarin hierdie mense hulle bevind, opvallend.

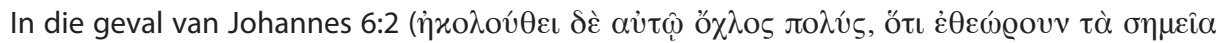

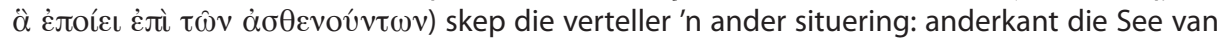
Galilea, teen 'n berg, waarheen die groot skare vir Jesus gevolg het omdat Hy die siekes genees het. Hierdie situering verwys egter net na die plek waarheen die skare vir Jesus gevolg het, en dui nie die situering aan waar die genesing van die siekes plaasgevind het nie, want volgens die verteller het die genesing van die siekes reeds vroeër in die verhaal plaasgevind. Om die waarheid te sê, presies waar hierdie genesing plaasgevind het, word nie vertel nie; dit moet as een van die "leë plekke"10 in die teks beskou word wat deur die leser gevul moet word, aangesien dié inligting nêrens anders in die verhaal gegee word nie. Dit kan op meer as een manier gedoen word. 'n Leser sou kon aanvaar dat ' $n$ hele groep genesings op verskillende plekke in Galilea plaasgevind het waarvan nie in die Evangelie vertel word nie. 'n Ander manier om die leë plek te vul, is om te dink aan genesings in sowel Judea as Galilea, en dan te aanvaar dat die twee genesings waarvan wel in die Evangelie vertel word (die genesing van die amptenaar se seun in Kana en die genesing van die verlamde man by die Bad van Betsata) hierby ingesluit word en partes pro toto as voorbeelde dien vir al die genesings wat in 6:2 veronderstel word. ${ }^{11}$ Enige van hierdie twee opsies is moontlik. Wat egter baie belangrik is om te besef, is dat daar een diskrepansie tussen die vermelding van die siekes in 6:2 en die vermelding van siekes by die genesing by die Bad van Betsata in 5:2-3 is, naamlik dat slegs een van die siekes wat langs die Bad van Betsata gesitueer word, genees is (die verlamde man), en dat die res nie genees is nie. Om dit anders te stel: die siekes wat in 6:2 genoem word en die siekes wat in 5:2-3 genoem word, kan nie dieselfde groep mense wees nie, aangesien die meeste van die siekes wat in 5:2-3 genoem word, nie genees is nie terwyl al die siekes wat in $6: 2$ genoem word, genees is.

Dit bring my by die derde aspek, naamlik die manier waarop die teks gelees word en die tipe leser

10. Kyk Iser (1976:257-355) vir die teoretiese aspekte rondom die vul van "leë plekke" ("Leerstellen") in tekste.

11. Dit is hoe Thyen (2005:335) dit interpreteer. 
NGTT Deel 54, Nommers 1 \& 2, Maart en Junie 2013

wat veronderstel word. Die soort lees van die teks wat in die vorige paragraaf beoefen is, kan as 'n lees téén die grein van die teks beskou word. Die bedoeling van die noem van die siekes (as randfigure) in Johannes 5:2-3 was waarskynlik net om 'n situering te skep vir die wonder wat kom. As randfigure moes hulle dadelik weer plek maak vir die verlamde op wie die fokus eintlik val. Dieselfde is waar van die siekes wat in Johannes 6:2 genoem word. Hulle word nie soseer ter wille van hulleself genoem nie, maar is eintlik net daar ter voorbereiding van dit wat volg, naamlik om 'n rede te bied vir die groot skare wat vir Jesus gevolg het. Ook in hulle geval is die bedoeling waarskynlik dat hulle dadelik uit die narratiewe wêreld verdwyn nadat hulle

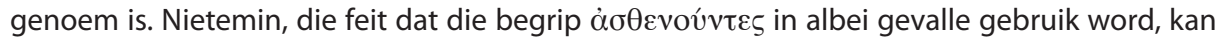
maak dat 'n leser die twee gedeeltes aan mekaar verbind en probeer om daaruit sin te maak. Dit kan op een van twee maniere gebeur:

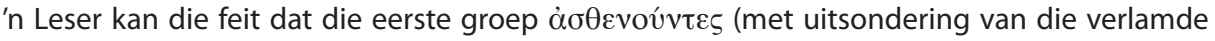
man) nie genees is nie, ignoreer, en bloot konsentreer op die tweede groep $\alpha \sigma \theta \varepsilon v o u ́ v \tau \varepsilon \varsigma$ wat genoem word. Dit kan dan gelees word as 'n verdere bevestiging van Jesus se identiteit, en as 'n verwysing na die baie ander wondertekens wat Hy gedoen het waarvan nie in die Johannesevangelie vertel word nie (vgl. hieroor ook Johannes 20:31).

'n Tweede opsie sou 'n weerstandige lees van die teks wees waarin 'n leser beide verwysings na $\alpha \sigma \theta \varepsilon v o u ́ v \tau \varepsilon \varsigma$ in balans probeer bring, deur nie aan een van die twee groepe ten koste van die ander voorrang te gee nie. So 'n leser sal dan in die geval van Johannes 5:2-3 begin om addisionele vrae te opper wat die leser wat in die vorige paragraaf veronderstel word, nie sou vra nie. Byvoorbeeld, vrae soos: "Wat het gebeur met die siekes by die Bad van Betsata wat nie genees is nie?", "Moes hulle die res van hulle lewens daar langs die bad slyt, sonder enige moontlike heling?"En miskien die belangrikste (ironiese) vraag: "Het hulle, wat langs die water gelê het, toe die Water van die Lewe misgeloop?"

Of is dit 'n geval dat lesers wat sulke tipe vrae vra, verkeerde vrae aan die teks stel? Moet 'n mens dalk vir jouself ' $n$ heeltemal ander tipe leser voorstel? ' $n$ Tipe leser vir wie genesing - die herstel van mobiliteit en sig, en so meer - nie die eintlike belangrike saak is nie. Dalk die tipe leser wat John Pilch (2000:138) in gedagte het as hy as volg skryf:

For persons in John's group whose relatives are ill or who themselves suffer from forms of immobility and blindness, the experience of the living Jesus in midst of the group brings restoration. It is access to the resurrected Messiah of Israel in altered state of consciousness (ASC) that enables results such as those reported in the significant healing interactions of Jesus?

\section{Samevatting}

Die bedoeling van hierdie kort studie was om 'n gaping in die navorsing oor die narratologiese interpretasie van die Johannes-evangelie te probeer vul. Ek vertrou dat ek hiermee aangetoon het dat dit nie nodig is om die toepassing van narratologiese benaderings te beperk tot die hoof- en kleiner karakters in die Johannes-evangelie nie. Randfigure soos die siekes kan inderdaad ook met sukses vanuit so 'n benadering ondersoek word! In hierdie spesifieke geval is aangetoon hoe die volgende narratologiese fasette met vrug gebruik kan word: klassifikasiesisteme vir karakters, 'n bespreking van die situering van karakters, asook 'n kritiese besinning van die manier waarop lesers sin kan maak van die (skrapse) inligting wat oor sulke karakters gebied word. In die geval van die ander randfigure in die Johannes-evangelie sou 'n 
NGTT: Oopbron - http://ngtt.journals.ac.za

mens dieselfde aspekte kon ondersoek, maar is dit dalk ook moontlik dat ander narratologiese aspekte (byvoorbeeld plot, fokalisasie en tyd) met vrug ondersoek sou kon word.

\section{BibLIOGRAFIE}

Barrett, C K 1978. The Gospel according to St John. An introduction with commentary and notes on the Greek text. London: SPCK.

Bauer, W, Arndt W F, Gingrich FW \& Danker FW 2000. A Greek-English lexicon of the New Testament and other early Christian literature. Chicago/London: University of Chicago Press.

Beck, D R 1993. The narrative function of anonymity in Fourth Gospel characterization. Semeia 63:143-158. Beekman, K D \& Fontijn J 1971. Roman-figuren I. Spektator 1:406-413.

Bennema, C 2009. Encountering Jesus: Character studies in the Gospel of John. Milton Keynes: Paternoster.

Berlin, A 1983. Poetics and interpretation of Biblical narrative. Sheffield: Almond Press. Bible and Literature.

Bieringer, R 2005. Mary Magdalene in the Four Gospels. Bible Today 43:34-41.

Bond, H K 1998. Pontius Pilate in history and interpretation. Cambridge: Cambridge University Press. MSSNTS 100.

Brodie, T L 1993. The Gospel according to John. A literary and theological commentary. New York - Oxford: Oxford University Press.

Brown, R E 1984. The Gospel according to John. Volume 2 (xiii-xxi). London: Geoffrey Chapman. AB.

Caron, G 1997. Qui sont les Juifs de l'Évanglie de Jean? Quebec: Bellarmin. Recherches 35.

Chatman, S 1978. Story and discourse. Narrative structure in fiction and film. Ithaca: Cornell University Press.

Conway, C M 1999. Men and women in the Fourth Gospel: Gender and Johannine characterization. Atlanta SBL. SBL.DS 167.

Culpepper, R A 1983. Anatomy of the Fourth Gospel. A study in literary design. Philadelphia: Fortress.

Davies, M 1992. Rhetoric and reference in the Fourth Gospel. Sheffield: JSOT Press. JSNTS 69.

De Boer, M C 2000. The narrative function of Pilate in John. In: G.J. Brooke \& J.-D. Kaestli (eds.), Narrativity in Biblical and related texts. La narrativité dans la Bible et les textes apparentés (Leuven: Leuven University Press/Peeters, BETL), pp. 141-158.

Dschulnigg, P 2002. Jesus begegnen: Personen und ihre Bedeutung im Johannesevangelium. Münster: LIT.

Fehribach, A 1998. The women in the life of the bridegroom: A feminist historical-literary analysis of the female characters in the Fourth Gospel. Collegeville, MN: Liturgical Press.

Forster, E M 1927. Aspects of the novel. New York: Harcourt Brace.

Haenchen, E 1980. Das Johannesevangelium. Ein Kommentar aus den nachgelassenen Manuskripten herausgegeben von Ulrich Busse mit einem Vorwort von James M. Robinson. Tübingen: J.C.B. Mohr (Paul Siebeck).

Hartenstein, J 2007. Charakterisierung im Dialog: Die Darstellung von Maria Magdalena, Petrus, Thomas und der Mutter Jesu im Kontext anderer frühchristlicher Traditionen. Göttingen: Vandenhoeck \& Ruprecht. NTOA 64.

Harvey, W J 1965. Character and the novel. London: Chatto \& Windus.

Hogan, L P 1992. Healing in the Second Temple Period. Freiburg/Göttingen:Universitätsverlag/Vandenhoeck \& Ruprecht. NTOA 21.

Howard, J K 2001. Disease and healing in the New Testament. An analysis and interpretation. Lanham/New York/Oxford: University Press of America.

Hunt, S A 2011. Rewriting the feeding of five thousand. John 6.1-15 as a test case for Johannine dependence on the Synoptic Gospels. New York: Peter Lang. Studies in Biblical Literature 125.

Iser, W 1976. Der Akt des Lesens. Theorie ästhetischer Wirkung. München: Fink. Uni-Taschenbücher 636.

Koester, C R 1995. Symbolism in the Fourth Gospel. Meaning, mystery, community. Minneapolis: Fortress.

Louw, J P \& Nida E A 1988. Greek-English lexicon of the New Testament based on semantic domains. Volume 1. Introduction and domains. New York: United Bible Societies.

Margolin, U 1987. Introducing and sustaining characters in literary narrative. Style 21:107-124.

Newman, B M \& Nida E A 1980. A translator's handbook on the Gospel of John. London - New York - Stuttgart: United Bible Societies. Helps for Translators.

Nicklas, T 2001. Ablösung und Verstrickung: "Juden" und Jüngergestalten als Charaktere der erzählten Welt des Johannesevangeliums und ihre Wirkung auf den impliziten Leser. Frankfurt am Main: Peter Lang. RST 60. 
NGTT Deel 54, Nommers $1 \& 2$, Maart en Junie 2013

Pilch, J 2000. Healing in the New Testament. Insights from medical and Mediterranean anthropology. Minneapolis: Fortress.

Resseguie, J L 2005. Narrative criticism of the New Testament. An introduction. Grand Rapids: Baker Academic. Rimmon-Kenan, S 1983. Narrative fiction. Contemporary poetics. London: Metheuen.

Ruschmann, S 2002. Maria von Magdala im Johannesevangelium: Jüngerin - Zeugin - Lebensbotin. Münster: Aschendorff.

Schneiders, S 1993. Women in the Fourth Gospel. In: M.W.G. Stibbe (ed.), The Gospel of John as literature. An anthology of twentieth-century perspectives (Leiden/New York/Köln: Brill, NTTS 17), pp. 123-143.

Taschl-Erber, A 2007. Maria von Magdala - erste Apostolin? Joh 20,1-18: Tradition und Relecture. Freiburg: Herder.

Thomas, J C 1995. 'Stop sinning lest something worse come upon you': The man at the pool in John 5. JSNT 59:3-20.

Thyen, H 2005. Das Johannesevangelium. Tübingen: Mohr-Siebeck. HNT 6.

Tuckett, C M 2000. Pilate in John 18-19. A narrative-critical approach. In: G.J. Brooke \& J.-D. Kaestli (eds.), Narrativity in Biblical and related texts. La narrativité dans la Bible et les textes apparentés (Leuven: Leuven University Press/Peeters, BETL), pp. 131-140.

Wiarda, T 2000. Peter in the Gospels. Pattern, personality and relationship. Tübingen: Mohr Siebeck. WUNT 2.127.

\section{TREFWOORDE}

Johannes-evangelie

Narratologiese analise

Karakterisering

Randfigure

Siekes

\section{KEY WORDS}

Gospel according to John

Narratological analysis

Characterization

Background characters

III people

\section{KONTAKBESONDERHEDE}

Prof. D Francois Tolmie

Departement Nuwe Testament

Fakulteit Teologie

Universiteit van die Vrystaat

Posbus 339

BLOEMFONTEIN 9300

Tel: 0514012667

E-pos: tolmief@ufs.ac.za 